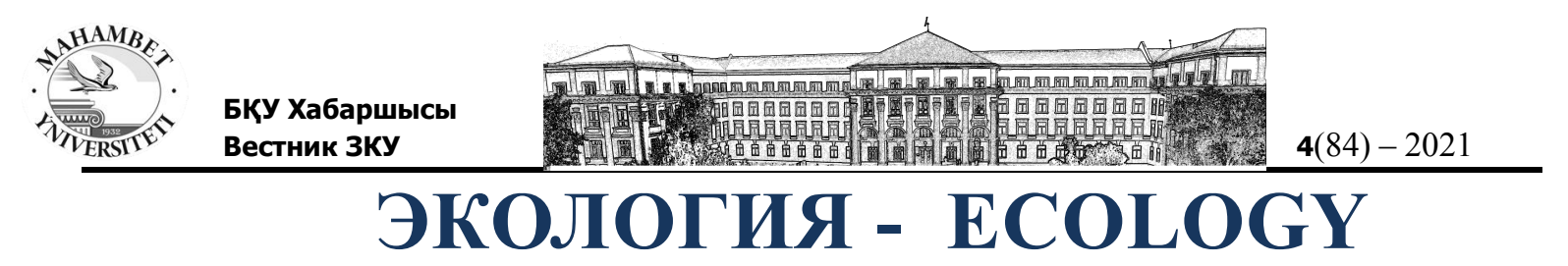

УДК 338.48

МРНТИ 71.37 .75

DOI 10.37238/1680-0761.2021.84(4).51

\author{
Макрушина И.В.*, Горбачева Д.А., Кружков Д.А. \\ ФГБОУ ВО «Кубанский государственный университет физической культуры, \\ спорта и туризма» \\ *Автор-корреспондент: makrinna@yandex.ru
}

\begin{abstract}
E-mail: makrinna@yandex.ru,gordiana1@mail.ru,deniskruzkov@gmail.com
ВНЕДРЕНИЕ ИННОВАЦИОННЫХ ПОДХОДОВ ОБСЛУЖИВАНИЯ В РАМКАХ ЭКОЛОГИЧЕСКОГО ТУРА
\end{abstract}

\begin{abstract}
Аннотация. B статье представлены инновационнье подходыл обслуживания туристов в рамках апитура, как вида экологического тура. На основании проведенного исследования рынка предложений туров среди туроператоров Краснодарского края, специализируюшихся на экотуризме, по результатам которого были выяснены наиболее популярные направления и выбран конкурентоспособный и новаторский вид «зеленого туризма» - апитуризм. Разработанный проект экологического тура с применением инновационных подходов обслуживания, ориентирован на семейный отдых в направлении апитуризма, который выявил потенциал региона для дальнейшего развития данного вида экотуризма. Определена экономическая эффективность тура через расчет его себестоимости, цены и точки безубыточности. Апитуры рассматриваются как самостоятельное направление экологического туризма. Разработанный тур одновременно отвечает критериям экотуризма, о чём говорит его начеленность на экологическое просвещение, и может предлагаться как инновачионный продукт в Краснодарском крае.
\end{abstract}

Ключевые слова: туризм, инновачии в туризме, инновачионные подходь, экологический туризм, инновационный экологический тур, турпродукт, Краснодарский край, целевая аудитория, программа экологического тура, апитур, глэмпинг.

\title{
Введение
}

Согласно Международному обществу экотуризма (The International Ecotourism Society) экотуризм определяется как путешествия в природные районы, которые сохраняют окружающую среду, поддерживают благополучие местного населения и включают обучение экологически ответственному туризму как гостей, так и персонала [1].

По оценкам экспертов, до начала распространения коронавирусной инфекции ежегодный прирост в этом сегменте мировой туристической отрасли составлял более $20 \%$. Почти каждый третий путешественник в мире - экотурист.

Экотуризм сегодня - это одно из самых перспективных направлений. Ввиду ограничений международных путешествий, развитие внутреннего туризма просто необходимо, и экотуризм может стать отличной альтернативой поездкам заграницу. Грамотно используя богатство природных и культурных ресурсов России в сочетании с инновационными подходами, можно создать турпродукт, отвечающий как требованиям экотуризма, так и современным тенденциям [2]. 
Согласно данным Всемирной туристской организации, ЮНВТО, инновации в туризме - это совместные действия между правительствами, научными кругами, корпорациями, микро-, малыми и средними предприятиями и стартапами, инвесторами, поддерживающими бизнес-партнерами и другими заинтересованными сторонами [3].

Инновация в туризме - это в основном постепенный процесс, который включает два компонента: нетехнологический компонент, зависящий от нематериальных человеческих ресурсов, организационной структуры и факторов, которые могут повысить ценность обслуживания клиентов (маркетинг, каналы сбыта), и технологический компонент, в настоящее время неотделимый от первого компонента, который зависит от технологий, особенно информационных и коммуникационных технологий [4].

Материалы и методы исследования

Цель исследования. Разработка инновационного экологического тура.

Задачи исследования: проанализировать предложения туроператоров Краснодарского края, специализирующихся на экотуризме; разработать экологический тур с применением инновационных подходов обслуживания.

Инновации в туристской деятельности - это результат действий, направленных на создание нового или изменение существующего туристского продукта, освоение новых рынков, использование передовых информационных и телекоммуникационных технологий, совершенствование предоставления туристских, транспортных и гостиничных услуг, создание стратегических альянсов для осуществления туристского бизнеса, внедрение современных форм организационно-управленческой деятельности туристских предприятий [5].

Конечным результатом работы туристского предприятия являются туристский продукт или услуга, а так как их создание - это сложный и многоступенчатый процесс, то внедрение инноваций возможно на различных его этапах. Несмотря на то, что общие принципы формирования инноваций и управления ими, принятые в других секторах экономики, могут применяться в туристской деятельности, научные подходы к определению инноваций в туризме еще не сформированы [6].

Экотуризм - это вид устойчивого туризма. Экотуризм и устойчивый туризм преследуют очень похожие цели. Устойчивый туризм фокусируется на путешествиях, которые оказывают минимальное воздействие на окружающую среду и местные сообщества, стараются улучшить впечатления для всех участников, учитывая при этом текущие и будущие экономические, социальные и экологические последствия. Устойчивый туризм имеет более широкую направленность и охватывает больше аспектов бизнеса, чем экотуризм. Например, помимо вовлечения сообществ, он также гарантирует, что люди получают справедливую оплату и работают в безопасных условиях. Но оба направления туризма нацелены на оказание положительного воздействия на местные сообщества, устойчивый экономический рост и минимизацию воздействия на окружающую среду, вызванного путешествиями [7].

Существует много споров о том, при каких пределах сохранение биоразнообразия, местной социально-экономические выгоды и воздействие на окружающую среду можно считать «экотуризмом». По этой причине экологи, группы с особыми интересами по-разному определяют экотуризм. Экологические организации обычно настаивают на том, что экотуризм основан на природе, устойчивом управлении, поддержке сохранения и экологическом образовании. Туристическая индустрия, однако, больше сосредотачиваются на продуктовом аспекте, часто рассматривая экотуризм как эквивалент любого вида туризма, основанного на природе.

Экотуризм включает в себя программы, которые сводят к минимуму негативные аспекты традиционного туризма для окружающей среды и повышают культурную самобытность местного населения. 


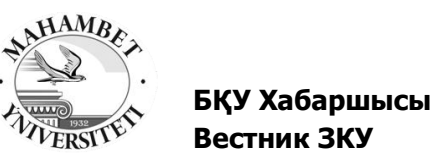

Широкое распространение сегодня получил апитуризм, который предлагает множество различных форм деятельности, такие как: ночевка в пчелином улье, дегустация медового вина, ингаляции воздухом улья и т.д. Россия на сегодняшний день имеет большой потенциал для развития данного вида туризма, так как само пчеловодство в стране начало свое развитие еще с пятнадцатого века и было по значимости не менее значимой отраслью, чем возделывание сельских культур [8].

Основной формой экотуризма является экологический тур (экотур) - это комплекс услуг по перевозке, размещению, питанию туристов, а также экскурсионные услуги, основными целями которых является посещение природных зон в целях охраны окружающей среды и рационального использования природных ресурсов.

Для того чтобы минимизировать возможное негативное воздействие или вовсе избежать его необходимо знать особенности экологического туризма, которые касаются его организации. В первую очередь это высокие требования к безопасности, которая состоит из личной безопасности туристов и их имущества, безопасности окружающей среды и используемых природных туристских ресурсов. При этом для разных видов экотуризма, будут свойственные ему риски: для горного - сход лавин, камнепад, сели, для водного падение в воду, опрокидывание плавсредства [9].

Экологический тур как вид туристской услуги на этапе создания представляет собой модель, включающую в себя несколько компонентов, которые являются его основой.

Обоснование выбора локации. Экологические туры могут осуществляться как в границах особо охраняемых природных территорий (акваторий), так и вне границ особо охраняемых природных территорий. При этом в первом случае будут предъявляться отдельные стандарты ввиду строгих требований к охране следующих территорий: государственные природные заповедники, национальные парки, государственные природные заказники, природные памятники, дендрологические парки и ботанические сады. А к турам, осуществляемым вне границ особо охраняемых природных территорий, можно отнести широкий спектр видов экологически ориентированного туризма: сельский, хардворктуризм, экстремальный, оздоровительный, природный и т.д.

Наличие экологического маршрута в программе тура. Экотуристский маршрут может быть добавлен с целью максимального познания природы и ее сохранения. Если в экологический тур будет включен маршрут, то необходимо обозначить его начальный и конечный пункты и построить путь следования, на котором предусмотреть наиболее безопасные места для стоянки, смотровых площадок, мест отдыха, выявить труднопроходимые участки и характерные для района опасности, выбрать посещаемые природные объекты и безопасный к ним подход, составить список необходимого техническое оснащения и снаряжения.

Информационное обеспечение и сопроводительный материал. Он может включать различные памятки о безопасности и правилах поведения, о погодных и климатических условиях района, выдаваемые туристам. Объекты, входящие в тур, рекомендуется оснащать туристской навигацией: схемы, табло, указатели и т.д. Информацию о посещаемых природных комплексах, природоведческих, краеведческих музеев, экотехнологичных хозяйств и иных объектов, предусматривающими изучение традиционных, аборигенных форм природопользования. Информирование туристов должно происходить как перед отъездом, чтобы свести к минимуму их негативное воздействие при посещении природных объектов, так и к каждой встрече с местными культурами, животными и растениями [10].

Необходимый персонал: инструктора-проводники, экскурсоводы, гиды и гидыпереводчики, - который имеет высокий уровень квалификаций и опыт участия в экологическом туре, особенно если он включает прохождение экотуристского маршрута. Все сотрудники должны поддерживать ценности экотуризма и участвовать во всех аспектах 
политики компании, чтобы предотвратить воздействие на окружающую среду и местную культуру.

Выбор средства размещения и транспорта, которым следует отвечать требованиям экологичности. Экотуризм стремится свести к минимуму неблагоприятное воздействие отелей, благоустроенных троп и другой инфраструктуры за счет использования либо переработанных, либо имеющихся в большом количестве местных строительных материалов, возобновляемых источников энергии, переработки и безопасного удаления отходов и мусора, а также архитектурного дизайна, отражающего окружающую среду и культуру. Рекомендуется использование велосипедов, безмоторных лодок, парапланов и других экологичных видов транспорта. Средства размещения также могут быть различных видов: гостиница, отель, туристская база, палаточный лагерь и т.д.

Повышение экологической осведомленности. Связь между экотуризмом и образованием заключается в том, чтобы созданный туроператором продукт эффективно интерпретировал ценности окружающей среды и местной культуры. Образование в этом контексте это больше, чем односторонняя передача информации. Речь идет о передаче положений экотуризма в такой форме, чтобы они были усвоены туристом, стали для него важными и ценными, смотивировали к бережному отношению к окружающей среде. Поэтому полагаться на вывески или брошюры неэффективно, личное общение здесь становиться просто необходимым. Образование может осуществляться как для туристов, так и для жителей близлежащих населенных пунктов. Экологическое просвещение заставляет более широкий круг людей осознавать необходимость ценить и защищать природные территории, ресурсы и культурное наследие.

Определение целевой аудитории. Экологический тур в зависимости от его содержания, включаемых объектов, наличия маршрута и его сложности может быть ориентирован на массовую аудиторию и изменен в соответствии с возрастом, полом, образованием, семейным положением, уровнем доходов, интересами и т.д.

Сегодня наблюдается возникновение новой группы клиентов в сфере устойчивого туризма, которые требуют от туроператоров создания различных видов деятельности и подходов к туризму, а также получение нового опыта - это экотуристы. Полное определение является предметом споров среди исследователей туризма. Некоторые исследования определяют экотуристов как тех, кто выбирает определенный опыт путешествия и направления, ориентированные на природу в нетронутой среде. Другие заявляют, что экотуристы также должны взаимодействовать с местным сообществом и приносить ему пользу. Более того, другое определение подчеркивает важность заинтересованности в расширении знаний о природе и приверженности делу устойчивости и сохранения окружающей среды, которую они используют в качестве места назначения, чтобы считаться экотуристами. Таким образом, экотуристов можно определить как людей, которые руководствуются принципами экотуризма при выборе и участии в туре.

Сложность создания экологического тура заключается в соблюдении баланса между получением финансовой прибыли для туристского предприятия и следованию основным принципам экотуризма при создании тура. Необходимо создать положительный опыт, как для участников тура, так и ценность для местных жителей и окружающей среде, доставив незабываемые впечатления туристам, повышая их осведомленность и чувствительность к местным экологическим, культурным или социальным вопросам.

Инновации - это ключевой элемент, который стимулирует экономику в секторе туризма. Туристический сектор требует различных видов инноваций, поскольку он является одним из самых конкурентоспособных. Предприятия в секторе туризма должны уделять все больше и больше внимания инновациям, если они стремятся извлечь выгоду из рыночной индустрии и сохранить свои позиции на рынке.

Совместив инновационные идеи и экотуризм, можно открыть новые возможности развития в направлении устойчивого туризма. 
Методы научного исследования, которые были применены для решения поставленных задач.

Анализ и обобщение данных научно-методической литературы ставил своей задачей изучение инноваций в туризме и организации экологических туров.

Метод сравнения использовался для изучения для изучения изменения уровня инноваций в туризме и его сегментах.

Метод проектирования применялся при непосредственной разработке экологического тура.

Метод аналогии использовался при разработке экологического тура для туристов на основе уже имеющихся предложений на отечественном туристском рынке.

С помощью метода описания были изложены итоги исследования развития инновации в туризме, их форм и их сочетание с экологическим туризмом.

Метод прогнозирования позволил предположить инновационность разработанного экологического тура среди туристов из Краснодарского края, а также из других субъектов Российской Федерации.

Потенциальной возможностью для развития может стать разработка новых турпродуктов по актуальным сегодня направлениям и видам туризма, внедрение инновационных подходов обслуживания и форм деятельности в туры.

\section{Результаты исследования}

Исходя из имеющихся на рынке предложений экологических туров по Краснодарскому краю, можно сделать выводы о целесообразности разработки экологического тура с инновационными подходами обслуживания и условиями развития туризма, направленного на внутренние направления. Разработка проекта экологического тура и расчет его экономической эффективности. В результате проведённого анализа предложений экологических туров был разработан проект экологического тура.

Направление - город-курорт Адлер привлекает большое количество туристов и обладает необходимыми ресурсами для развития апитуризма.

Цель - развитие экологического туризма в Краснодарском крае посредством создания инновационного тур продукта.

Замысел - предоставление комплексной услуги (экотур), включающей различные формы деятельности, туристам в соответствии с основными принципами экологического туризма.

Инновационность - апитуризм как полноценная форма отдыха и развлечения.

Целевая аудитория представлена в таблице 1.

Таблица 1 - Целевая аудитория экотура

\begin{tabular}{|l|l|}
\hline \multicolumn{1}{|c|}{ Признаки } & \multicolumn{1}{|c|}{ Характеристика } \\
\hline Географический & Жители Адлера, Краснодарского края \\
\hline Демографический & $\begin{array}{l}\text { Пол - женский, мужской. Относительно молодые, } \\
\text { экономически активные люди (25-44 года), } \\
\text { путешествующие в основном семьями (с детьми). }\end{array}$ \\
\hline Социально-экономический & $\begin{array}{l}\text { Образование - среднее специальное, неполное высшее и } \\
\text { высшее. Уровень дохода - средний, выше среднего. }\end{array}$ \\
\hline Психографический & $\begin{array}{l}\text { Физическая и психологическая выносливость - средняя. } \\
\text { Предпочтения в активном отдыхе, отдыхе на природе, } \\
\text { познавательной и творческой деятельности в кругу семьи. }\end{array}$ \\
\hline Поведенческий & $\begin{array}{l}\text { Путешествующие с целью укрепить семейные } \\
\text { отношения, воспитать в детях интерес к родному краю, } \\
\text { бережное отношение к природе. Предпочитают отдых } \\
\text { длительностью 4-7 дней. }\end{array}$ \\
\hline
\end{tabular}

Составлено автором 


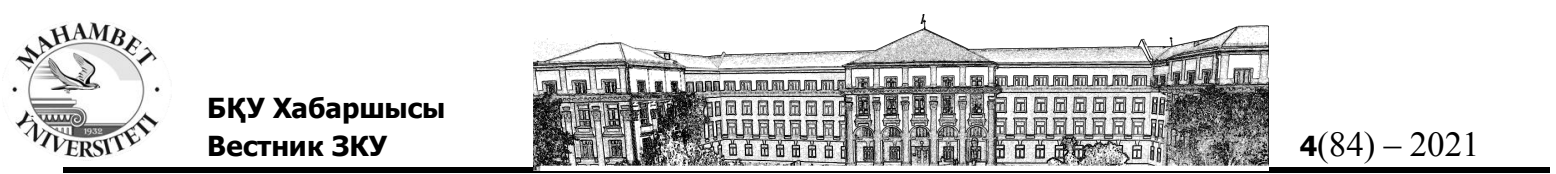

Количество человек в группе: 10.

Продолжительность: 5 дней/4 ночи.

Период проведения: весна-лето.

Проживание: кемпинг «Адлер туризм», тип размещения - эко-юрты, питание - 6разовое.

\section{Описание программы}

Первый день - знакомство с апитуризмом. Тур начинается со встречи с гидом на автовокзале Сочи. После приветствия туристов отвезут в село Высокое, где находится кемпинг «Адлер туризм», в котором они будут проживать на протяжении всего тура. Данный объект соответствует модному на сегодняшний день средству размещения - глэмпингу, который одновременно сочетает в себе как комфорт, так и близость к природе. Предлагается вариант размещения в палатках или в эко-юртах. Эко-юрта представляет собой специальное жилище, которое состоит из деревянного каркаса, обтянутого тканью (войлоком), внутри расположены деревянные кровати. Благодаря южному климату в юрте сохраняется тепло. На территории также расположены мобильная баня, бассейн, зона для массажа, столовая зона, душевые с водонагревателем. Питание организовано 6 раз в день, которое состоит из местных свежих фруктов и овощей, Кавказского меда, лечебного чая. Есть меню для вегетарианцев.

После заселения и обеда будет проведена экскурсия на пасеку «В гостях у Гамзата», в которую входит рассказ владельца о пчеловодстве и оздоровительных и косметических рецептах с использованием меда, о том как правильно выбирать мёд, дегустация различных сортов мёда с чаем на травах и вином. В конце можно приобрести качественные продукты пчеловодства: мед, маточное молочко, цветочную пыльцу, прополис и др. Для детей будет интересна традиционная форма апи-фольклора - рисование на ульях. Например, красочные картинки, украшающие передние панели пчелиных домиков, могут изображать сцены и персонажей из народных сказок. Кроме того, пчеловоду намного легче запомнить положение определенной пчелиной семьи, покрасив переднюю панель улья.

Но при проведении экскурсии на пасеке необходимо учесть важные условия, которые обезопасят туристов:

- соответствие пасеки стандартам пчеловодства: наличие паспорта пасеки, справки о качестве мёда, документы на реализацию продукции, ветеринарное свидетельство;

- туристы обязаны строго соблюдать правила посещения пасеки,

- для более комфортного обслуживания туристов пасеку лучше разбить на две части: в одной - проводить экскурсии, а другую часть оставить пчелам, чтобы они могли там спокойно работать, собирая нектар и пыльцу.

После экскурсии у туристов будет свободное время, а ночью их ждёт наблюдение за астрономическими явлениями в зоне отдыха. Благодаря этому экологичному мероприятию путешественники смогут не только насладиться чистым ночным небом в открытой сельской местности, но и узнать для себя много нового о космосе, используя специальные приложения на смартфонах, которые сегодня есть у каждого.

Второй день - медовые рецепты. После завтрака туристы отправляются в комплекс «Озеро Ачигварское», где им предстоит попробовать рыбалку на берегу живописного озера. Данное озеро отличает богатый улов рыбы ценных пород: осетр, форель, канадский сом, карп, сазан, белый амур, африканский сом. После рыбалки будет показан мастер-класс по приготовлению рыбы в медовом маринаде. Есть чем заняться и детям - по территории комплекса свободно гуляют павлины, Римские гуси, утки, индоутки, декоративные петушки, лебеди, цесарки, которых можно покормить.

По возвращению в кемпинг гостей ждёт еще один рецепт, который им предстоит приготовить всей семьей: медовые пряники. Первые пряники на Руси появились примерно в 
IX веке и назывались «медовым хлебом». Название русских пряников происходит от слова «пряный», это обусловлено рецептурой сладости - изначально пряники делали из ржаной муки, смешанной с медом и ягодным соком, но позже, когда Россия начала торговать с Индией и Ближним Востоком, начали импортироваться экзотические специи, которые часто добавляли для ароматизации теста. Для пряников с начинкой можно использовать измельченные орехи, мед, варенье, карамель или фруктовую пасту. Традиционно для лепки используются специальные деревянные доски, которые позволяют придать лакомству самые разнообразные формы. На следующий день им можно будет полакомиться в походе.

Третий день - по следам природы. В этот день туристам предстоит отправиться в удивительный эко-маршрут «Альпийские луга». Альпийские луга являются частью Сочинского национального парка. Название обусловлено тем, что этот термин применяется для горных лугов, которые находятся на отметках от 1600-2000 метров и начинаются от верхней границы горных лесов, и простираются до тех отметок, где начинается пояс вечных снегов и ледников. Здесь можно увидеть краснокнижные высокогорные цветы и кустарники, горных коз - серн. Для отдыха оборудованы беседки, в которых можно остановиться на пикник. Помимо животных и растений по пути можно встретить древние постройки ацангуары. Эти сооружения из необработанных камней носили функцию загонов для скота, который здесь пасли горные племена. Виды Альпийских лугов идеально подойдут для фотографий со всей семьей, поэтому взрослым и детям предлагается поучаствовать в фотоохоте, в ходе которой им предстоит отыскать определенные виды растений, животных, объекты. Так они смогут узнать для себя что-то новое, поучаствовать в совместной семейной деятельности.

Следующим объектом будет Тисо-самшитовая роща, тропы которой идеально подойдут для знакомства с природой субтропического климатического пояса. Реликтовый лес является частью двух охраняемых территорий: Кавказского заповедника и Сочинского национального парка. Представителями флоры являются ягодный тис и вечнозеленый колхидский самшит, весной цветут дикие цикломены. Дикие звери около троп не появляются, за исключением ящериц, ежей и птиц. В Роще три маршрута: Большое кольцо (5 км), Малое кольцо (1, 6 км) и тропа «В глубь веков» (800 м). Маршруты удобно стыкуются и переходят друг в друга, поэтому для более увлекательного времяпрепровождения семьям предлагается поучаствовать в геокэшинге - игре, суть которой состоит в нахождении тайников, спрятанных другими участниками игры. Для каждой семьи будет выдана карта рощи с отметкой приза - это может быть, например, сундучок с мёдом, специями, сладостями.

Оба маршрута является частью Сочинского национального парка, одной из форм деятельности которого является участие в формировании экологического сознания и развития основ экологической культуры населения, поэтому парк предлагает услуги экскурсовода.

Так как весь день туристы проведут на маршрутах, то приём пищи предлагается в форме питательных перекусов, организованный кухней кемпинга.

Как и при посещении любого природного объекта, нахождение на маршруте подразумевает соблюдение строгих правил, которые не только обезопасят нетронутые уголки природы, но и туристов. Поэтому перед походом необходимо провести инструктаж, рассказав о требованиях и рекомендациях нахождения на маршруте.

Четвертый день - оздоровление. Заключительный день путешествия туристам предлагается провести в парк-отеле «Дивный» в Лазаревском районе города Сочи. Комплекс занимает территорию более 7 гектар, которая включает всю необходимую инфраструктуру. Для размещения построены уютные эко-коттеджы, выполненные в традициях русского деревянного зодчества из деревянного бруса с разнообразными категориями номеров. 


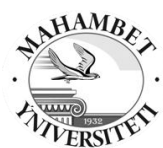

Питание организовано в ресторане на воде на берегу живописного озера Дивного, где вы можно отведать блюда восточной, кавказской и европейской кухни.

Восстановить силы и расслабиться можно в банном комплексе, который включает финскую и русскую парильни, купель с ледяной водой, чайную комнату. Для комплексного восстановления действует оздоровительный центр, предлагающий услуги терапевта и косметолога, СПА-программы, различные виды массажей, бювет с минеральной водой «Лазаревская» и фитобар. Кроме того, в парк-отеле практикуют ульетерапию.

Семьям предлагается познать апитуризм в нескольких формах. В память о путешествии они пройдут мастер-класс по созданию свечей из натурального пчелиного воска (вощины), слои которого пропитаны эфирными маслами и травами.

В течении дня ознакомятся с несколькими видами апитерапии: массаж медом, сон на ульях и дыхание пчелиным воздухом. Мед - древнее средство по уходу за кожей, которое сегодня пользуется огромной популярностью. Медовый массаж сохраняет кожу эластичной, питает и освежает её. В зависимости от техники этот вид массажа может быть очень расслабляющим, а запах меда создает эффект ароматерапии.

Сон на ульях - процедура, суть которой состоит в отдыхе над местом обиталища пчел. Проводится она в специальных домиках, обычно с двумя лежанками, под которыми находятся пчелиные семьи. Пчелы залетают в улей с другой стороны сооружения, помещение надежно изолировано, поэтому угрозы для человека нет. Сочетание микровибрации, ароматерапии и звука пчелиного жужжания погружает человека в глубокий сон и восстанавливает его организм за 30-60 минут. Было зарегистрировано множество случаев положительного эффекта при ревматических, дерматологических, урологических, гинекологических, эндокринологических, респираторных и опорно-двигательных заболеваниях. Наилучшие результаты были получены при заболеваниях верхних дыхательных путей. Аллергию на пыльцу можно вылечить путем регулярного и своевременного вдыхания воздуха из ульев.

Таким образом, программу тура можно представить в таблице 2.

Таблица 2 - Программа экологического тура. Составлено автором

\begin{tabular}{|c|l|}
\hline Дата & \multicolumn{1}{|c|}{ Программа } \\
\hline 1 день & $11: 00$ - встреча с гидом на автовокзале Сочи \\
& $11: 30$ - трансере в село Высокое (36 км) \\
& $12: 30$ - заселение в глэмпинг «Адлер туризм» и обед \\
& $14: 00$ - путь до пасеки \\
& $14: 30$ - экскурсия «В гостях у Гамзата»: лекция, дегустация, рисование на ульях \\
& $18: 30$ - возвращение в кемпинг и свободное время \\
& $22: 00$ - «Ночь астрономии» \\
\hline 2 день & $8: 00$ - подъём и завтрак \\
& $10: 00$ - трансфер до Ачигварского озера \\
& $11: 00$ - рыбалка и мастер-класс по приготовлению рыбы с медом \\
& $16: 00$ - возвращение в кемпинг и приготовление медовых пряников \\
& $18: 00$ - свободное время \\
\hline 3 день & $7: 00$ - подъём и завтрак \\
& $9: 00$ - трансфер к подъёмникам \\
& $10: 00$ - подъём на канатной дороге и прохождение эко-маршрута «Альпийские луга» \\
& $14: 00$ - трансфер к Тисо-самшитовой роще \\
& $15: 00$ - прохождение маршруга посредством геокэшинга \\
& $18: 00$ - возвращение в кемпинг и свободное время \\
\hline 4 день & 6:00 - подъём и завтрак, сборы \\
& $8: 00$ - трансфер в Сочи \\
& $10: 00$ - прибытие в парк-отель «Дивный». В течение дня прохождение мастер-класса по созданию свечей из \\
& воска, массаж и сон на ульях \\
\hline 5 день & 8:00 - подъём и завтрак, сборы \\
& $10: 00$ - отправление домой \\
\hline
\end{tabular}


Процесс определения экономической эффективности турпродукта включает в себя три этапа: расчет себестоимости турпродукта, расчет цены турпродукта и дохода от его реализации, оценку экономической эффективности. Себестоимость туристского продукта представлена в таблице 3.

Таблица 3 - Расчет себестоимости тура. Составлено автором

\begin{tabular}{|l|c|c|c|}
\hline \multicolumn{1}{|c|}{ Наименование статьи затрат } & Тип издержек & $\begin{array}{c}\text { Стоимость } \\
\text { на группу } \\
\text { (10 чел.), } \\
\text { руб. }\end{array}$ & $\begin{array}{c}\text { Стоимость } \\
\text { на 1 чел., } \\
\text { руб. }\end{array}$ \\
\hline Размещение и питание & Переменные & 45000 & 4500 \\
\hline Экскурсия на пасеку & Переменные & 3000 & 300 \\
\hline Ачигварское озеро: вход & Переменные & 6000 & 600 \\
\hline Прокат удочки & Переменные & 4000 & 400 \\
\hline Мастер класс по приготовлению рыбы & Переменные & 5000 & 500 \\
\hline Мастер-класс по приготовлению пряников & Переменные & 8000 & 800 \\
\hline Маршрут «Альпийские луга», экскурсовод & Переменные & 15500 & 1550 \\
\hline $\begin{array}{l}\text { Маршрут «Тисо-самшитовая роща», } \\
\text { экскурсовод }\end{array}$ & Переменные & 4000 & 400 \\
\hline $\begin{array}{l}\text { Размещение в отеле «Дивный» (питание, } \\
\text { массаж и сон на ульях включены) }\end{array}$ & Переменные & 40000 & 4000 \\
\hline Мастер-класс по изготовлению свечей & Переменные & 12000 & 1200 \\
\hline Автобус (10 часов) & Постоянные & 10000 & 1000 \\
\hline ИТОГО & & 152500 & 15250 \\
\hline
\end{tabular}

Таким образом, себестоимость тура составила 15250 руб. на человека. Минимальное количество человек в группе 10. Соответственно себестоимость тура на группу из 10 человек составит 152500 руб. В стоимость тура заложим процент рентабельности на уровне $17 \%$.

Сегодня, ввиду ограничений на международные путешествия, разработка новых предложений во внутреннем туризме становится актуальным предметом обсуждения, поэтому развитая инновационная деятельность на туристском предприятии очень важна в условиях высокой конкуренции. Разработка совершенно нового направления, использование инновационных форм обслуживания и деятельности в туре, позволит сформировать уникальный турпродукт, который потенциально может принести прибыль предприятию, а в случае экологического туризма и местному населению.

\section{Заключение}

На основании проведенного исследования рынка предложений туров среди туроператоров Краснодарского края, специализирующихся на экотуризме, по результатам которого были выяснены наиболее популярные направления и выбран конкурентоспособный и новаторский вид «зеленого туризма» - апитуризм. Разработанный проект экологического тура с применением инновационных подходов обслуживания, ориентирован на семейный отдых в направлении апитуризма, который выявил потенциал региона для дальнейшего развития данного вида экотуризма. Определена экономическая эффективность тура через расчет его себестоимости, цены и точки безубыточности.

Апитуры рассматриваются как самостоятельное направление экологического туризма. Разработанный тур одновременно отвечает критериям экотуризма, о чём говорит его нацеленность на экологическое просвещение, и может предлагаться как инновационный продукт в Краснодарском крае. 
Разработанный экологический тур требует соблюдения определенных норм является основой для инновационных подходов обслуживания:

1) Вид размещения - глэмпинг - не только отвечает принципу экотуризма в организации отдыха среди природы, но и предлагает комфортные условия туристам: от проживания в уютной юрте до кухни с местными блюдами.

2) Экскурсионная программа представлена как образовательными методами - лекции, дегустации, так и развлекательными - мастер-классы.

3) Экомаршруты предлагается пройти в игровой форме посредством геокэшинга и фотоохоты, а «Ночь астрономии» с использованием приложений на смартфоне.

4) Мастер-классы, полноценно раскрывающие апитур через приготовление блюд с мёдом, создание свечей и рисование на ульях будут интересны туристам и принесут доход местному населению.

5) Тур включает и оздоровительную программу: медовый массаж и ароматерапию, сон на ульях.

Экологический тур в сочетании с инновациями на сегодняшний день может составить конкуренцию на внутреннем рынке туризма и принести пользу как туроператорам, так и индустрии в целом.

Таким образом, инновации имеют важное значение в туризме, поскольку туристические направления, которые участвуют в более инновационных разработках, с большей вероятностью будут предпочтены туристами, учитывая конкурентный характер глобальных рынков. Они играют ключевую роль в открытии новых рынков, поскольку потребности туристов с каждым годом становятся более разнообразными и их сложнее выявить.

\section{ЛИТЕРАТУРА}

[1] Ассоциация экологического туризма: [сайт] / учредитель Ассоциация экологического туризма. - Москва, 2021. - URL http://www.ecotourism-russia.ru

[2] Малыгина, Н.В. Экологический туризм: учебное пособие / Н.В. Малыгина. - М.: Прометей, 2019. - 163 с.

[3] Всемирная туристская организация: [сайт] / учредитель ЮНВТО - Мадрид, 2021. - URL: https://www.unwto.org

[4] Новиков, В.С. Инновации в туризме: учебное пособие / В.С. Новиков. - М.: ИЦ Академия, 2017. - 208 с.

[5] Anishchenko, M. Ecotourists' motivation and its relation to the ecotourism's principles / M. Anishchenko. // Journal of Ecotourism. - 2016. - № 8. - P. 223-236.

[6] Cano, X. P. Innovation typology in tourism. Master Thesis / X. P. Cano. - Universitat de Girona, 2018. - P. 9-17.

[7] Genc, R. Market-oriented innovations in tourism / R. Genc // Research in Hospitality Management. - 2017. - № 7. - P. 51-57.

[8] Плотникова, В.С. Современное состояние и перспективы развития апитуризма в Республике Карелия / В.С. Плотникова, А.М. Федоров // Экономика, предпринимательство и право. - 2020. - № 5. - С. 1491-1508.

[9] Ивлиева, О.В. Природные туристские ресурсы мира: учебное пособие / О.В. Ивлиева. - Ростов-на-Дону: Южный федеральный университет, 2018. - 247 с.

[10]Турклуб ECOADVENTURE: [сайт] / учредитель OOO «Страна-Реинфо». - Сочи, 2021. - URL https://ecoadventure.ru/ 


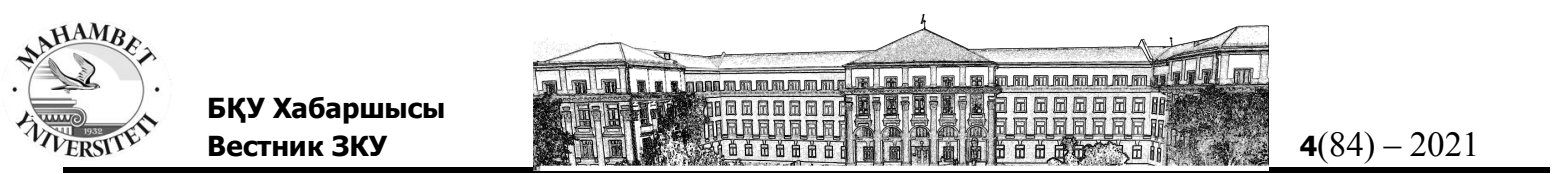

REFERENSES

[1] Sait Associaciya ekologicheskogo turizma [Site of the association of ecological tourism]. Retrieved from http://www.ecotourism-russia.ru [in Russian].

[2] Malygina, N.V. (2019) Ekologicheskij turizm: uchebnoe posobie [Ecological tourism: teaching aid]. Moscow: Prometej [in Russian].

[3] Vsemirnaya turistskaya organizaciya [World Tourism Organization]. Retrieved from https://www.unwto.org [in Russian].

[4] Novikov V.S. (2017) Innovacii v turizme: uchebnoe posobie [Innovations of tourism: teaching aid] Moscow: IC Akademija [in Russian].

[5] Anishchenko M. (2016) Ecotourists' motivation and its relation to the ecotourism's principles Journal of Ecotourism,8, 223-236. [in English].

[6] Cano X. P. Innovation typology in tourism. [Master Thesis] Universitat de Girona, 917. [in English].

[7] Genc R. (2017) Market-oriented innovations in tourism. Research in Hospitality Management, 7, 51-57. [in English].

[8] Plotnikova V.S. \& Fedorov A.M. (2020) Sovremennoe sostoyanie i perspektivy razvitiya apiturizma $\mathrm{v}$ Respublike Kareliya [Current state and development prospects of apitourism] . Ekonomika, predprinimatel'stvo i pravo - Economy, enterprenership and law, 5, 14911508. [in Russian].

[9] Ivlieva O.V. (2018) Prirodnye turistskie resursy mira: uchebnoe posobie [Natural tourist resources of the world: teaching aid]. Rostov-na-Donu: YUzhnyj federal'nyj universitet [in Russian].

[10]Turklub ECOADVENTURE [ECOADVENTURE Tourism club]. Retrieved from https://ecoadventure.ru/ [in Russian].

\section{Макрушина И.В., Горбачева Д.А., Кружков Д.А. ЭКОЛОГИЯЛЫК ТУР ШЕНБЕРІНДЕ ҚЫЗМЕТ КӨРСЕТУДІҢ ИННОВАЦИЯЛЫҚ ТӘСІЛДЕРІН ЕНГІЗУ}

Андатпа. Мақалада экологиялық турдың бір түрі ретінде апитура аясында туристерге қызмет көрсетудің инновациялық тәсілдері келтірілген. Экотуризмге мамандандырылған Краснодар өлкесінің туроператорлары арасында туристік ұсыныстар нарығын зерттеу негізінде ең танымал бағыттар анықталды және "жасыл туризма" бәсекеге қабілетті және инновациялық түрі - апитуризм таңдалды. Инновациялық т тәсілдерін қолдана отырып жасалған экологиялық тур жобасы апитуризм бағытында отбасылық демалыстарға бағытталған, бұл аймақтың экотуризмнің осы түрін одан әрі дамыту үшін әлеуетін анықтады. Турдың экономикалық тиімділігі оның құнын, бағасын және сыну нүктесін есептеу арқылы анықталады. Апитуралар экологиялық туризмнің дербес бағыты ретінде қарастырылады. Әзірленген тур сонымен бірге экотуризм өлшемдеріне сәйкес келеді, бұл оның экологиялық ағартушылыққа бағытталғандығымен сипатталады және Краснодар өлкесінде инновациялық өнім ретінде ұсынылуы мүмкін.

Кілт сөздер: туризм, туризмдегі инновациялар, инновациялық тәсілдер, экологиялық туризм, инновациялық экологиялық тур, туристік өнім, Краснодар аймағы, мақсатты аудитория, экологиялық тур бағдарламасы, апитур, глэмпинг. 


\section{Makrushina Inna, Gorbacheva Diana, Kruzhkov Denis INTRODUCTION OF INNOVATIVE SERVICE APPROACHES WITHIN THE FRAMEWORK OF THE ECOLOGICAL TOUR}

Annotation. The article presents innovative approaches to the service of tourists within the framework of the aperture as a type of ecological tour. Based on the study of the market of tourist offers among the tour operators of the Krasnodar Territory specializing in ecotourism, the most popular destinations were identified and a competitive and innovative type of "green tourism" apitourism was selected. The ecotourism project, developed using innovative methods of tourism, is focused on family holidays in the direction of apitourism, which determined the potential of the region for the further development of this type of ecotourism. The economic efficiency of the tour is determined by calculating its cost, price and break-even point. Applicants are considered as an independent direction of ecological tourism. The developed tour also meets the criteria of ecotourism, which is characterized by its focus on environmental education and can be presented as an innovative product in the Krasnodar Territory.

Keywords: tourism, innovations in tourism, innovative approaches, ecological tourism, innovative ecological tour, tourist product, Krasnodar territory, target audience, ecological tour program, apitur, glamping. 